\title{
ZMIERZCH PANOWANIA TURECKIEGO NA BAŁKANACH POLITYCZNE, SPOŁECZNO-KULTUROWE I MILITARNE UWARUNKOWANIA SCHYŁKU WŁADANIA BOŚNIĄ I HERCEGOWINĄ PRZEZ OSMANÓW
}

\author{
DANUTA GIBAS-KRZAK
}

\begin{abstract}
The decline of the Turkish rule in the Balkans. The political, socio-cultural and military conditions of the end of the Ottoman Empire in Bosnia and Herzegovina.

The aim of this paper is to present a paradigm according to which Bosnia and Herzegovina can be seen as a mirror in which the multifaceted problems of Turkey as the "sick person of Europe" are reflected. Contributing to the Turkish withdrawal from the Balkans, however, the Ottoman legacy characterized by political and cultural fragmentation permanently became a part of the history of the Balkans and influenced its fate in the 21st century. The author, on the basis of the studies of the American, Polish, Turkish, Bosnian, Serbian and Croatian historians examines the factors that determined the end of Ottoman rule in the Balkans. Bosnia and Herzegovina should be considered the key to the analysis of the Eastern crisis (1875-1878), which proved to be a mere preludes prelude to the end of the Ottoman Empire. The characteristic feature of this province was its permanent insubordination against Turkey, visible in a great number of revolts and uprisings of different provenance against the Turkish government. Already at the beginning of the 17th century, increasing corruption and taxes imposed on the Muslim population led to the first protests against the government. In the 17th century the great uprisings of Bosnian Muslims took place in the following years: 1636, 1650, 1682. In Herzegovina unrest and riots were reported in the following years: $1711,1727,1728,1729,1732$. The Ottoman sources confirmed the occasional participation of the Christian population in those riots. On the one hand, the Muslim feudal lords, who were opposed to the reforms of the Sultan and fought to maintain their privileges, acted against the central power. On the other hand, rebellions had the character of the people's liberation movement. The largest peasant revolt against the Muslim feudal lords from 1875 in Herzegovina rapidly evolved into the rise of Christian peasants all over Bosnia and Herzegovina, at the same time, the uprising became the South Slavic war of liberation from Turkish rule, contributing to the collapse of the Ottoman Empire.
\end{abstract}

Autor: Danuta Gibas-Krzak, Akademia im. Jana Długosza w Częstochowie, ul. Waszyngtona 4/8 42-200 Częstochowa, email: stanczyk2@o2.pl

Słowa kluczowe: Imperium Otomańskie, Bośnia i Hercegowina, kryzys wschodni, polityczna i kulturalna fragmentacja, mozaika religijna

Keywords: the Ottoman Empire, Bosnia and Herzegovina, the Eastern crisis, political and cultural fragmentation, religious mosaic

Balcanica Posnaniensia. Acta et studia, XXII/2, Poznań 2015, Wydawnictwo Instytutu Historii UAM, pp. 15-36, ISBN 978-83-63047-88-7, ISSN 0239-4278. Polish text with a summary in English.

Celem niniejszej analizy jest zaprezentowanie paradygmatu, zgodnie z którym Bośnia i Hercegowina stanowi klucz do analizy „wielkiego kryzysu wschodniego" (1875-1878), stanowiącego preludium kresu Imperium Otomańskiego. Przyjęto założenie, że Bośnia i Hercegowina może być postrzegana jako lustro, w którym zostały 
odzwierciedlone wieloaspektowe problemy pogrążonej w kryzysie Turcji, co w konsekwencji doprowadziło do wyparcia Osmanów z Bałkanów, zaś spuścizna państwa sułtanów, charakteryzująca się fragmentaryzacją polityczną i kulturową na trwale wpisała się w dzieje Bośni i Hercegowiny, determinując jej współczesne dzieje polityczne. Podstawą do napisania analizy stała się literatura przedmiotu, autorstwa badaczy z Europy Zachodniej, Turcji, Chorwacji, Bośni i Hercegowiny, a także Serbii ${ }^{1}$ oraz monografie polskich autorów, spośród których do najważniejszych należy zaliczyć opracowania: Jerzego Skowronka, Mieczysława Tantego ${ }^{2}$, Tadeusza Wasilewskiego ${ }^{3}$, Jana Reychmana ${ }^{4}$, Henryka Batowskiego ${ }^{5}$, Antoniego Gizy ${ }^{6}$ oraz Tomasza Witucha ${ }^{7}$.

\section{UWARUNKOWANIA ZEWNĘTRZNE I WEWNĘTRZNE ZMIERZCHU PAŃSTWA SUŁTANÓW W XVIII I XIX WIEKU}

Zmiana sytuacji międzynarodowej w XVIII w. nieuchronnie prowadziła Turcję do upadku, zaprzepaszczając szansę kontynuowania świetności z okresu podbojów prowadzonych przez Mehmeda II Zdobywcę, prawie bezpośrednio zagrażającego Rzymowi, który w Watykanie zamierzał zatknąć zwycięski znak Półksiężycaoraz,,złotej epoki” Imperium Osmańskiego ${ }^{8}$ zapanowaniaSulejmanaWiel-

${ }^{1} \mathrm{~W}$ tej grupie opracowań do istotnych należy zaliczyć następujące monografie: Marcel Bazin, Stéphane de Tapia, Turcja. Geografia wschodzacej potęgi, Dialog, Warszawa 2014; Dzieje gospodarcze i społeczne imperium osmańskiego 1300-1914, red. Halil Inalcik, Donald Quataert, Wyd. Uniwersytetu Jagiellońskiego, Kraków 2008; Misha Glenny, The Balkans 1804-1999. Nationalism, War and the Great Power, Viking, London 2000; Barbara Jelavich, Historia Batkanów. Wiek XVIII i XIX, t. I., Wyd. Uniwersytetu Jagiellońskiego, Kraków 2005; William Miller, The Ottoman Empire 1801-1913, Cambridge University Press, Cambridge 1913; Milorad Ekmečić, Ustanak u Bosni, Veselin Masleša, Sarajevo 1960; Mustafa Imamović, Historija države i prava, Magistrat Sarajevo, Sarajevo 2003; Noel Malcolm, Bosnia. A short history, Pan Books, London 2002; Bernard Lewis, Narodziny nowoczesnej Turcji, PWN, Warszawa 1972; Robert J. Donia, Sarajevo: biografija grada, Institut za Istoriju u Sarajevu, Sarajevo 2006; Robert J. Donia, John V. A. Fine, Jr., Bosna i Hercegovina: iznevjerena tradicija, Institut za Istoriju u Sarajevu, Sarajevo 2011.

2 M. Tanty, Konflikty bałkańskie w latach 1878-1918, Państwowe Zakłady Wydawnictw Szkolnych, Warszawa 1968; Idem, Bosfor i Dardanele w polityce mocarstw, PWN, Warszawa 1982; Idem, Batkany wXX wieku. Dzieje polityczne, Książka i Wiedza, Warszawa 2003.

3 J. Skowronek, M. Tanty, T. Wasilewski, Historia Słowian Południowych i Zachodnich, PWN, Warszawa 1988.

${ }^{4}$ J. Reychman, Historia Turcji, Zakład Narodowy im. Ossolińskich, Wrocław-Warszawa-KrakówGdańsk 1973.

${ }^{5}$ H. Batowski, Państwa bałkańskie 1800-1923. Zarys historii dyplomatycznej i rozwoju terytorialnego, Kasa im. Mianowskiego w Warszawie, Kraków 1938.

${ }^{6}$ A. Giza, Idea jugoslawizmu w latach 1800-1918, Wyd. Naukowe US, Szczecin 1992; idem, Bośnia i Hercegowina $w$ dobie tureckiego i austriackiego panowania (1800-1914), Wyd. Naukowe US, Szczecin 2002.

7 T. Wituch, Tureckie przemiany. Dzieje Turcji 1878-1923, PWN, Warszawa 1980.

8 Tylko w Europie upowszechniła się nazwa Imperium Osmańskie, poza tym stosowano nazwy: Porta Otomańska lub Wysoka Porta, zaś Turcy określali posiadane przez siebie terytoria jako Devlet-i âl.-i 
kiego 9 . Kontynuowanie polityki podbojów skutecznie uniemożliwiły czynniki zewnętrzne, do których należy zaliczyć przede wszystkim liczne wojny, prowadzone zwłaszcza z Polską, a później z Rosją; oraz wewnętrzne - rozsadzające państwo ruchy narodowowyzwoleńcze $\mathrm{w}$ podbitych prowincjach oraz nieskutecznie realizowane reformy, często bojkotowane przez zdobywających coraz większe wpływy możnowładców ${ }^{10}$. Tureckie działania ekspansjonistyczne - skierowane przeciwko Zachodowi - nie miały dalszych szans rozwoju także dlatego, iż żaden z kolejnych padyszachów nie dorównywał wybitnym poprzednikom, ponadto brak nowoczesnej armii udaremnił odnoszenie zwycięstw na polach bitewnych ${ }^{11}$.

Efektem licznych wojen toczonych w omawianym okresie było kurczenie się powierzchni państwa sułtanów oraz osłabienie jego znaczenia na arenie międzynarodowej. Przegrana w wojnie z Rosją, prowadzonej w latach 1768-1774, która została określona jako druzgocąca katastrofa militarna i dyplomatyczna, dokonała całkowitej transformacji układu sił w rejonie Morza Czarnego. Starcia militarne zakończył traktat w Küczük-Kainardży (Kücük Kajnarca), zdecydowanie obniżający prestiż Turcji na arenie międzynarodowej, w wyniku którego Imperium Otomańskie poniosło znaczne straty terytorialne, musiało dokonać roszczeń reparacyjnych ponad swoje możliwości ${ }^{12}$, a ponadto zapewnić rosyjskiej flocie handlowej swobodę żeglugi przez Bosfor i Dardanele oraz prawo do opieki nad Kościołem prawosławnym i jego wyznawcami na terytorium państwa Osmanów ${ }^{13}$.

Następstwem kolejnej wojny z Rosją i Austrią, zakończonej pokojem w Jassach w 1792 r., było, co prawda, niewielkie okrojenie terytorium Turcji, ale Rosja urosła do rangi największego zagrożenia dla bytu państwa padyszachów ${ }^{14}$. Niewątpliwie jednym z fundamentalnych skutków wojen rosyjsko-tureckich, prowadzonych za panowania Katarzyny II Wielkiej, było utracenie przez Turcję na rzecz Rosji wpływów

Osman, czyli Państwo Osmana, M. Kunt, Ch. Woodhead, Süleyman Magnificent and his Age, Longman, London and New York 1995, s. 5-6.

${ }^{9}$ Sulejman Wspaniały (panował w latach 1520-1566) dzięki silnej flocie stworzył potęgę Osmanów, których panowanie rozciągało się w basenie Morza Śródziemnego, północnej Afryce i na Bliskim Wschodzie. Apogeum swojego wzrostu państwo sułtanów osiągnęło w okresie wielkich odkryciach geograficznych, M. Tanty, Bosfor i Dardanele..., s. 17.

${ }^{10}$ M. Tanty, Konflikty batkańskie..., s. 6.

11 F. Babinger, Z dziejów Imperium Osmanów. Sultan Mehmed Zdobywca i jego czasy, PIW, Warszawa 1977, s. 503-504. Wielu badaczy wskazało, że w wyniku zawarcia pokoju w Karłowicach w 1699 r. nastąpił pierwszy podział Imperium Otomańskiego, który dał początek jego nieuchronnemu rozkładowi, W. Miller, The Ottoman Empire..., s. 1-3 et passim.

12 Dzieje gospodarcze i społeczne imperium..., s. 618.

13 Turcja zrzekła się m. in. zwierzchności nad Chanatem Krymskim. W ten sposób Krym stał się protektoratem rosyjskim i w 1783 r. został ostatecznie anektowany przez Rosję, B. Jelavich, Historia Bałkanów..., s. 78-79. Traktat w Küczük-Kainardży wzmocnił pozycję Rosji w Grecji, Rumunii i wśród Słowian Południowych, co sprzyjało rozsadzaniu imperium od środka, J. Reychman, Historia Turcji..., s. 175.

14 Pokój w Jassach potwierdził aneksję chanatu krymskiego, dokonaną w 1783 r. Turcja zrzekła się pretensji do Gruzji, na Kaukazie rzeka Kubań stała się rzeką graniczną pomiędzy Rosją a Turcją, Rosja otrzymała ziemie między Bohem i Dniestrem, B. Jelavich, Historia Bałkanów..., s. 80. 
nad Morzem Czarnym, które przestało być pojmowane jako „tureckie jezioro"15. Zasadnicza przyczyna klęsk militarnych Osmanów wynikała z zaniechania reform wojskowych, zwłaszcza w zakresie techniki wojennej, która nie zmieniła się od połowy XVI w., gdy tymczasem zarówno w Europie Zachodniej, jak też w Rosji wprowadzano szereg innowacji. Armia turecka, która nie dysponowała wysokim potencjałem militarnym, była znacznie gorzej wyszkolona i słabiej wyposażona, zaś jej liczebność nie przekraczała 100000 żołnierzy ${ }^{16}$. Kawaleria spahisów, którzy odgrywali wiodącą rolę w dziele wielkich podbojów, stawała się coraz mniej skuteczna w rywalizacji z wrogą piechotą, mającą na wyposażeniu broń palną ${ }^{17}$. Jak zauważyła Barbara Jelavich, korpus janczarów, niegdyś ślepo oddany władcy, pod koniec swego funkcjonowania, znalazł się w kryzysie, przypominając: „,bandę awanturników, zdolnych bardziej do obalania osmańskich rządów $i$ wywotywania anarchii $w$ prowincjach niż do obrony państwa przed obcymi najeźdźcami ${ }^{18}$. Jego członkowie koncentrowali się głównie na dworskich intrygach i gromadzeniu majątku, torpedując działalność reformatorską, inicjowaną przez władzę centralną.

W drugiej połowie XVIII w. w dyplomacji europejskiej rozwinęła się tzw. kwestia wschodnia, obejmująca problematykę rozpadającego się Imperium Otomańskiego oraz dziedzictwa po nim, która charakteryzowała się rywalizacją mocarstw, zaś rozwiązanie problemu tureckiego $\mathrm{w}$ związku z pytaniem o przyszłość posiadłości tego imperium stało się istotnym problemem w polityce międzynarodowej, a także czynnikiem determinującym działania najważniejszych graczy na arenie międzynarodowej $^{19}$.

W historii państwa Osmanów wiek XIX bywa często nazywany „najdłuższym wiekiem imperium”, głównie ze względu na podjęcie dalekosiężnych procesów reformatorskich, które miały doprowadzić do transformacji państwa ${ }^{20}$. Faktycznie, po wojnie krymskiej ${ }^{21}$ kontynuowano sanację państwa w ramach reform tanzimatu, które były realizowane w latach 1839-1876. Program naprawczy objął zmiany w różnych

15 M. Tanty, Bosfor i Dardanele..., s. 46.

16 J. Skowronek, M. Tanty, T. Wasilewski, Historia Słowian Południowych..., s. 243. Flota osmańska, której okres świetności przypadał na koniec XV w., w latach 70. XVI w. dysponowała tylko trzystoma okrętami. Braki technologiczne, opóźnienia w rozwoju sztuki walk na morzu, sztywne utrzymywanie galer - sprawiły, że podobnie jak cała armia turecka, także i flota charakteryzowała się niskim potencjałem militarnym. Odpowiadająca bardziej nowoczesnym standardom marynarka wojenna powstała dopiero w drugiej połowie XVIII w. Składała się m. in. z okrętów liniowych oraz fregat, które jednak zostały prawie doszczętnie zniszczone podczas $\mathrm{V}$ wojny rosyjsko-tureckiej, w bitwie morskiej pod Czesmą (1770 r.), W. Morawski, S. Szawłowska, Wojny rosyjsko-tureckie od XVII do XX wieku, Wyd. Trio, Warszawa 2006, s. 82.

17 B. Jelavich, Historia Bałkanów..., s. 58.

18 Ibidem, s. 272.

19 J. Skowronek, M. Tanty, T. Wasilewski, Historia Stowian Południowych ..., s. 244.

20 Vide: И. Ортајли, Најдужи век империје, Српска кнјижевна задруга, Београд 2004.

21 Wojna krymska, prowadzona w latach 1853-1856, przyniosła zwycięstwo Turcji oraz jej sojusznikom: Wielkiej Brytanii, Francji i Piemontowi, którzy upokorzyli carat, zdobywając Sewastopol. W jej efekcie doszło do zdemilitaryzowania Morza Czarnego, wstrzymując ekspansję Rosji - największego wroga państwa sułtanów, B. Jelavich, Historia Bałkanów..., s. 277-278. Opowiedzenie się po stronie 
dziedzinach: prawie i administracji, skarbie, wojskowości, systemie edukacji. Żadne z podejmowanych działań nie podważały jednak zasad teokracji sułtańskiej ${ }^{22}$. Wobec tego nie nastąpiła także zmiana charakteru państwa, stanowiącego imperium muzułmańskie, rozumiane jako wspólnota wyznawców islamu, w którym sułtan sprawował władzę absolutną. Dekadencja Imperium Otomańskiego widoczna była zwłaszcza na tle państw europejskich, które szybko się modernizowały, gdy tymczasem państwo sułtanów nie tyle podupadało, ile drastycznie dystansowało się od postępów cywilizacyjnych Starego Kontynentu ${ }^{23}$. Ponadto także inne uwarunkowania wewnętrzne - polegające na wzroście pozycji lokalnych feudałów oraz niedomaganiu administracji - stanowiły kolejny czynnik dezintegracyjny. Dzięki stale powiększanym majątkom paszowie, sandżak - bejowie czy ajanowie uniezależniali się od władzy centralnej, zdobywając wysoką pozycję i zagrażając władzy sułtana. Takich możnowładców jak Ali Pasza z Tepeleny ${ }^{24}$, panujący w południowej Albanii, Epirze i części Grecji, było znacznie więcej. Wymownym przykładem zbuntowanego poddanego był zarządca Egiptu, Mehmed Ali, który otwarcie wystąpił przeciwko padyszachowi, docierając w 1832 r. do Anatolii, gdzie jego wojska zdruzgotały całkowicie armię turecką, której pomocy musiała udzielić Rosja ${ }^{25}$.

$\mathrm{Na}$ początku kryzysu wielkie mocarstwa były skłonne wspierać padyszachów, aby krach osmańskiego giganta nie załamał ładu w Europie, lecz pod koniec XIX w. wykazywały nie tylko tendencje ekspansjonistyczne i chęć dokonanie rozbioru Turcji, zwanego „chorym człowiekiem” Europy ${ }^{26}$, ale także dążyły do uzależnienia gospodarczego i opanowania tureckich rynków zbytu ${ }^{27}$. Liczne wojny, na które zaciągano pożyczki we Francji i Wielkiej Brytanii rujnowały Turcję, coraz bardziej uzależnioną ekonomicznie od wielkich graczy ${ }^{28}$. Przy czym, należy zgodzić się

Osmanów zachodnie mocarstwa traktowały jako szczególne poświęcenie, którego celem było wymuszenie reform wewnętrznych przez państwo padyszachów, W. Miller, The Ottoman Empire ..., s. 298.

22 M. Bazin, S. de Tapia, Turcja. Geografia ..., s. 53-54.

23 T. Wituch, Tureckie przemiany..., s. 11.

24 Ali pasza, znany jako „Lew z Janiny”, opiewany m. in. przez Byrona, początkowo trudnił się rozbojami. Uzbrojony przez Turków, szybko skierował się przeciwko nim, zdobywając pozycję suwerena, dzięki której mógł poprzeć Greków w ich walce o niepodległość. Został pokonany dopiero przez wojska sułtana Mahmuda II w 1822 r., A. Koseski, Albania. Krótki zarys dziejów, Książka i Wiedza, Warszawa 1988, s. 33-35.

${ }^{25}$ Niemniej jednak Mehmed Ali zdobył władzę dziedziczną nad prowincją egipską, M. Tanty, Konflikty batkańskie..., s. 5.

${ }^{26}$ Stwierdzenie to przypisuje się carowi Rosji, Mikołajowi I, który określił w ten sposób Turcję w rozmowie z G. H. Seymourem, ambasadorem brytyjskim w Petersburgu: „Mamy na rękach chorego człowieka, bardzo chorego człowieka. Człowiek jest umierający. Można podać mu lekarstwo, ale nawet ono nie utrzyma go przy życiu", Zygmunt Stefan Zalewski, Dardanele $i$ Gallipoli w polityce $i$ strategii mocarstw europejskich podczas I wojny światowej, Wyd. Uniwersytetu Warmińsko-Mazurskiego, Olsztyn 2001, s. 13; T. Aronson, Zwaśnieni monarchowie. Europejskie trony w przeddzień katastrofy 1914 roku, Wyd. Literackie, Kraków 2014, s. 135.

27 J. Reychman, Historia Turcji..., s. 250.

${ }^{28}$ W 1854 r. na prowadzenie wojny krymskiej Porta wynegocjowała 3000000 funtów szterlingów od rządów Wielkiej Brytanii i Francji. Kolejną pożyczkę w wysokości 5000000 państwo sułtanów uzyskało w 1855 r. Oferujące wsparcie finansowe, wielkie mocarstwa, za wszelką cenę chciały utrzymać przy 
ze zdaniem Mishy Glenny’ego, który stwierdził, iż kres państwa sułtanów nastąpił w wyniku splotu wielu czynników: akumulacji długu państwowego, fiaska reformy agrarnej, wybuchu zamieszek społecznych oraz rozwoju świadomości narodowej na Bałkanach $^{29}$. Istotne pole sporu stanowiła jednak rozgrywka o rozległe terytoria tego regionu, zamieszkałe przez ludność słowiańską, gdzie najsilniej rozwijały się tendencje wyzwoleńcze narodów podporządkowanych do tej pory Wysokiej Porcie ${ }^{30}$. W ten sposób doszło do wywołania ,wielkiego kryzysu wschodniego”, zakończonego rozejmem w San Stefano i traktatem berlińskim, który przyniósł zasadnicze zmiany na mapie Bałkanów ${ }^{31}$.

\section{SPECYFIKA TERYTORIUM POGRANICZA, CZYLI BOŚNIA I HERCEGOWINA W PAŃSTWIE OSMAŃSKIM}

Podbój terytorium Bośni i Hercegowiny przez Osmanów miał charakter wieloetapowy, trwał prawie sto lat i był procesem zróżnicowanym w zależności od regionu kraju. Najnowsze badania kwestionują tezę, iż z powodu partykularnych interesów wielmożów średniowieczne królestwo bośniackie nie było zdolne do kontynuowania samodzielnego bytu. Piotr Wróbel zwrócił uwagę, że w ostatnich latach istnienia Bośnia wykazywała dużą aktywność na arenie międzynarodowej, następowało wzmocnienie pozycji króla, jednocześnie słabło znaczenie możnowładców, którzy wyczerpali się w walkach między sobą ${ }^{32}$. Upadek królestwa Bośni nastąpił więc nie z powodu przyczyn dezintegracyjnych odnoszących się do sytuacji wewnętrznej państwa, lecz jego bezpośrednią przyczyną stał się czynnik militarny, bowiem ostateczny krach królestwa nastąpił w wyniku jednego, wielkiego uderzenia

życiu państwo tureckie, aby nie dopuścić do uzyskania przez Rosję wpływów w rejonie cieśnin Bosfor i Dardanele. Jednak ogromne wydatki Osmanów, m. in. na rozwój floty, sprawiły, iż w 1875 r. Imperium Otomańskie ogłosiło bankructwo. Niektórzy analitycy uznali, że ,,wielki kryzys wschodni” został spowodowany przez turecką rozrzutność i przesadzoną lekkomyślność w udzielaniu kredytów przez Zachód, M. Glenny, The Balkans 1804-1999..., s. 86- 90.

29 Ibidem, s. 85.

30 Aby umocnić swoją pozycję wobec mocarstw zachodnich, narody bałkańskie od lat 60. XIX w. nadaremnie próbowały stworzyć blok militarno-polityczny, który mógłby zabezpieczyć ich interesy, H. Batowski, Podstawy sojuszu bałkańskiego 1912. Studia z historii dyplomatycznej 1806-1912, Polskie Towarzystwo dla Badań Europy Wschodniej i Bliskiego Wschodu, Kraków 1939, s. 33-90.

31 „Wielki kryzys wschodni” obejmował szereg konfliktów, które doprowadziły do fundamentalnych przekształceń politycznych na Bałkanach. Wojna rosyjsko-turecka 1877-1878 oraz kończące ją traktaty pokojowe stanowiły ich ważną część, J. Rubacha, Idea trwałego związu w Europie Południowo-Wschodniej a skutki II wojny bałkańskiej, [w:] Konflikty militarne i niemilitarne na Bałkanach w XX i XXI wieku w perspektywie polemologicznej, pod red. Danuty Gibas-Krzak i Andrzeja Krzaka, Wyd. Zapol, Szczecin-Warszawa 2013, s. 49.

32 P. Wróbel, Krzyż i Półksiężyc. Zachodnie Bałkany wobec Turcji w latach 1444-1463, Wyd. Historia Iagellonica, Kraków 2000, s. 172-173. 
armii tureckiej, które nastąpiło wiosną $1463 \mathrm{r} .{ }^{33}$. Za nieprawdziwe natomiast należy uznać twierdzenie, że Bośnia upadła „po cichu” (,šapatom pala”) z powodu zdrady heretyków, członków unikalnego kościoła bośniackiego (zwanych często bogomiłami), którzy mieli dopuścić się zdrady, wydając kraj Turkom ${ }^{34}$. Srećko Džaja zwrócił uwagę, iż w chwili najazdu Osmanów Kościół bośniacki praktycznie nie istniał, wcześniej bowiem uległ rozbiciu, natomiast kolaborację jego wyznawców z siłami tureckimi należy uznać za pomówienie, dokonane przez dostojników Kościoła katolickiego, których celem było zniesławienie konkurencyjnego wobec Watykanu - kościoła bośniackiego ${ }^{35}$.

Wraz z okupacją turecką nastąpiło usunięcie średniowiecznych instytucji związanych z bośniackim królestwem, nastąpiły także dalekosiężne przemiany demograficzne, społeczne oraz religijne ${ }^{36}$. Terytorium królestwa zostało podzielone na trzy części (sandżaki), które stanowiły część elajetu Rumelii: Bośnia (ze stolicą w Sarajewie), Zvornik (obejmował zachodnią część obecnej Serbii) oraz Hercegowina (ze stolicą w Fočy, przeniesioną - w 1572 r. do Pljevlja) ${ }^{37}$. Na opanowanym obszarze Osmanowie utworzyli system timarów, na których osadzano spahijów z terenów wcześnie opanowanych lub oddawano w lenno ziemię miejscowym feudałom, którzy przeszli na islam, natomiast mieszkańcy pozostali przy wierze chrześcijańskiej nie mieli możliwości zachowania majątków i przywilejów. W Bośni i Hercegowinie dominowały wielkie lenna hasa, należące do sułtana, sandżak-beja Bośni i timary,

33 Ibidem, s. 188; Idem, Oblicza islamizacji na terenach Bośni w XV i połowie XVI wieku, „Balcanica Posnaniensia. Acta et studia" nr XVIII, 2001, s. 84.

34 M. Filipović, Bosna i Hercegovina, najvažnije geografske, demografske, historijske, kulturne i političke činjenice, Compact-E, Sarajevo 1997, s. 74.

35 Informacje o zdradzie bogomiłów były rozpowszechniane nie tylko przez przedstawicieli Kościoła katolickiego, lecz także przez zachodnich dyplomatów, S. M. Džaja, Konfesionalnost $i$ nacionalnost Bosne i Hercegovine. Predemancipacijsko razdoblje 1463.-1804., ZIRAL, Mostar 1999, s. 27, 40 et passim. O bogomilizmie i kościele bośniackim vide: N. Malcolm, Kościół Bośniacki, „Krasnogruda” nr 7 , 1997; M. M. Petrović, Pomen bogomila - babuna u Zakonopravilu Svetoga Save i „,Crkva Bosanska”, Novi dani, Beograd 1995; S. Runciman, Manicheizm średniowieczny, Marabut, Gdańsk 1996; I. Detkova, Bogomilismo e dualismo iranico. Il „,neomanicheismo”, Alma Mater Studiorum Università di Bologna, Bologna 2008; J. Spyra, Bogomilizm w Europie południowo-wschodniej. Powstanie, rozwój, organizacja, „Studenckie Zeszyty Historyczne Uniwersytetu Jagiellońskiego”, III, Historia, Z. 2, 1983; Idem, Wspólnoty bogomilskie jako próba powrotu do form życia gmin wczesnochrześcijańskich, „Zeszyty Naukowe Uniwersytetu Jagiellońskiego", DCCCVII, Prace Historyczne, z. 84, 1987; P. Ćošković, Crkva bosanska u XV. stoljeću, Institut za Istoriju, Sarajevo 2005; J. Šidak; ,Crkva Bosanska” i problem bogumilstva u Bosni, Izdanje Matice Hrvatske, Zagreb 1940; Sima M. Ćirković, The Bosnische Kirche, Accademia Nazionale dei Lincei, Roma 1964; S. M. Džaja, Srednjovjekovna Crkva bosanska u procijepu suprotstavljenih kontekstualizacija „Status” br. 10, jesen 2006.

36 Źródła dotyczące problemów etnicznych i religijnych Bośni w XV w. należy określić jako niewystarczające, dlatego też występuje wiele spekulacji na temat dziejów tych ziem w okresie średniowiecza oraz po podboju tureckim, S. M. Džaja, Konfesionalnost i nacionalnost Bosne i Hercegovine ..., s. 46-47.

37 Robert J. Donia, John V. A. Fine, Jr., Bosna i Hercegovina..., s. 49. W 1865 r. w ramach sanacji państwa powstał wilajet Bośni, który składał się z siedmiu okręgów, co miało służyć przyśpieszeniu reform podjętych w ramach tanzimatu, K. Krysieniel, W cieniu Dayton. Bośnia i Hercegowina między etnokracją i demokracja konsocjonalna, Wydawnictwo Sejmowe, Warszawa 2012, s. 93. 
na których osiedlali się spahijowie z sułtanatu. Od schyłku XVI w. spahijowie uzyskali na własność ziemię, tworząc czyftliki, na których osadzali chłopów oraz jeńców wojennych. W 1558 r. powstały pograniczne kapetanie, które wraz z upływem czasu osiągały coraz większe znaczenie, jako instytucje prawie niezależne od władzy centralnej ${ }^{38}$.

W literaturze przedmiotu zazwyczaj eksponowany jest fenomen Bośni i Hercegowiny jako terytorium, którego mieszkańcy po podboju tureckim masowo przechodzili na islam. Było to tym łatwiejsze, iż w początkowej fazie zdobywania wpływów Osmanowie nie wymagali od konwertytów szczególnej religijności, lecz jedynie formalnego zadeklarowania się i politycznej lojalności. W związku z tym islamizacja często była powierzchowna, ponadto istniało wiele grup kryptochrześcijan (szczególnie do XVI w.) oraz występował charakterystyczny dla bośniackiego islamu synkretyzm, którego istotną cechą było islamskie, teologiczne tłumaczenie chrześcijańskich elementów ${ }^{39}$. W ten sposób na ziemiach Bośni i Hercegowiny doszło do ukształtowania się specyficznej mozaiki konfesyjnej, ze znaczną liczbą muzułmanów, wiernych Turkom, która stała się istotnym czynnikiem kształtowania się terytorium niestabilnego, przyczyniając się do rozwoju konfliktu na linii chrześcijanie muzułmanie.

Zgodnie z danymi przedstawionymi przez Muhameda Hadžijahicia, liczba ludności wynosiła w 1732 r. - 340 000, w tym muzułmanów - 198 000, katolików 30 000, prawosławnych - 113 000. W 1789 r. - Bośnię i Hercegowinę zamieszkiwało 600000 ludności, z czego 265000 - stanowili muzułmanie, 79000 - katolicy i 253000 - prawosławni, natomiast w 1817 r. - liczbę mieszkańców oszacowano na 600 000, w tym 200000 muzułmanów, 50000 - katolików oraz 350000 - prawosławnych ${ }^{40}$. W ciągu kolejnych kilkudziesięciu lat doszło do znacznego wzrostu liczby ludności, na co wskazują dane przekazane przez Đorđe Pejanovicia. Według nich w 1879 r. terytorium to zamieszkiwało 1158164 osoby, w tym liczbę mieszkańców wyznania prawosławnego oszacowano na 496 485, katolików - 209391 i muzułmanów $448613^{41}$. Warto zauważyć, iż w ciągu wieków panowania tureckiego, w wyniku postępującej islamizacji ${ }^{42}$, doszło do znaczącego wzrostu liczby muzułmanów, którzy posiadali przywileje, niedostępne dla chrześcijańskich poddanych

38 W. Felczak, T. Wasilewski, Historia Jugosławii, Zakład Narodowy im. Ossolińskich, Wrocław 1985, s. 204-205.

39 P. Wróbel, Oblicza islamizacji..., s. 96-97.

${ }^{40}$ M. Hadžijahić, Neki rezultati ispitivanja etničkih kretanja u Bosni u XVIII i prvoj polovici XIX stoljeća, „Prilozi Instituta za istoriju”, br. 11/12, 1976, s. 289-292.

41 Ђ. Пејановић, Становништво Босне и Хериеговине, Српска Академија Наука, Београд 1955, s. 46.

42 Struktura etniczna Bośni i Hercegowiny zmieniła się w istotny sposób na przełomie XVI/XVII w., gdy doszło do masowej islamizacji, chociaż nadal istniała znaczna grupa kryptochrześcijan, którzy jedynie deklaratywnie przyjęli islam. Znaczący wkład w proces islamizacji wnieśli janczarzy, których pobór był największy na tym terytorium, E. Weibel, Histoire et géopolitique des Balkans de 1800 à nos jours, Ellipses, Paris 2002, s. 45. 
sułtana ${ }^{43}$. Wyznawcy niemuzułmańskich religii funkcjonowali w państwie padyszachów na zasadzie tzw. milletów, czyli wspólnot wyznaniowych, cieszących się znaczną autonomią, w ramach których załatwiano wszystkie kwestie prawno-majątkowe i sądowe, lecz poza którymi ludność niemuzułmańska nie posiadała żadnych praw $^{44}$. Postępowanie Turków - poprzez politykę klasyfikowania poddanych zgodnie z milletami - doprowadziło do wzmocnienia znaczenie religii jako determinanty tożsamości oraz nadało instytucjom religijnym funkcje polityczne. Podziały religijne, które ukształtowały się jako konsekwencja podboju tureckiego, zdominowały solidarność etnokulturową, natomiast religia stała się istotnym czynnikiem dezintegracji struktur społecznych, doprowadzając do osłabienia poczucie etnicznej wspólnoty $^{45}$. Konsekwencje tego stanu rzeczy są aktualne do dzisiaj, bowiem następstwem panowania tureckiego jest skomplikowana sytuacja etniczna, jak również brak jednoznacznie ukształtowanej tożsamości narodowej, zgodnie z którą współczesnej Bośni i Hercegowiny nie zamieszkują Bośniacy w znaczeniu politycznym i narodowym, lecz jedynie Muzułmanie, Chorwaci i Serbowie, a każdy z tych narodów posiada własny pogląd na historię i charakter polityczny państwa.

Niewątpliwie dzieje Bośni i Hercegowiny, silne uzależnione od historycznych i geopolitycznych uwarunkowań tego obszaru, stały się podstawą do prezentowania przez wielu badaczy paradygmatu pogranicza kulturowego - rozumianego jako pogranicze narodowe oraz cywilizacyjne, na terytorium którego doszło do powstania muzułmańskiej wspólnoty narodowej oraz tzw. boszniackiej tożsamości, ukształtowanej w opozycji do narodów - chorwackiego oraz serbskiego ${ }^{46}$.

Pokłosie panowania osmańskiego jest dostrzegalne na każdym kroku we współczesnej Bośni i Hercegowinie, gdzie dokonuje się mitologizacji przeszłości, aby uzasadnić tezę, iż islam stał się czynnikiem umożliwiającym historyczną i kulturową kontynuację Bośni i Hercegowiny - jako jednostki politycznej, gdyż został przyjęty przez bogomiłów, czyli przez „dobrych Bośniaków”. Przy czym wielu naukowców pochodzenia muzułmańskiego wskazuje na iunctim między średniowiecznym kościołem bogomilskim a islamem. W świetle jednak współczesnych badań teorie te należy

43 Wysokość podatków płaconych przez muzułmanów nie stanowiła nadmiernego obciążenia, natomiast ludność chrześcijańska wraz z utrwalaniem panowania tureckiego została zmuszona do ponoszenia znacznych obciążeń fiskalnych, co miało duży wpływ na jej sytuację ekonomiczną (zubożenie). Niebagatelne znaczenie miał też fakt, iż chłopi pozostający w zależności feudalnej od właścicieli majątków (głównie muzułmanów) w większości byli chrześcijanami, M. Džaja, Konfesionalnost i nacionalnost Bosne..., s. 90 et passim.

44 T. Wituch, Tureckie przemiany..., s. 13

45 Robert J. Donia i John V. A. Fine, Jr., Bosna i Hercegovina..., s. 75; My już jesteśmy zjedzeni... Rola i znaczenie prawosławia w konflikcie etnicznym w Dolinie Preszewa, praca zbiorowa pod red. R. Zenderowskiego, Wyd. Instytut Politologii Uniwersytetu Kardynała Stefana Wyszyńskiego w Warszawie, Warszawa 2012, s. 17 et passim.

46 L. Moroz-Grzelak, The Specifity of the Bosnia and Hercegovina Borderland and the Issue of Bosnian Identity, „Sprawy Narodowościowe” nr 31, 2007, s. 307- 315; V. Spahić, Bośniacko-muzutmańska tożsamość kulturowa między zasadami mocy i pokoju [w:] Wokół Macedonii: siła kultury, pod red. B. Zieliński, Wyd. Naukowe UAM, Poznań 2002, s. 221-229. 
ocenić jako iluzoryczne, odnoszące się bardziej do pogranicza mitologii i fantazji, niż par excellence do realiów historycznych ${ }^{47}$, służą one bowiem wyłącznie celom politycznym, czyli uzasadnieniu dominacji muzułmanów w systemie politycznym tego państwa.

\section{KSZTAŁTOWANIE SIĘ PARADYGMATU BOŚNIACKIEJ NIESTABILNOŚCI}

Spoglądając na dzieje Bośni i Hercegowiny, można stwierdzić, iż odzwierciedlają one kryzys, w obliczu którego stanęło Imperium Otomańskie po czterech wiekach panowania na Starym Kontynencie. Trzeba podkreślić, że w zasadzie od początku podboju tureckiego występował na tym terytorium duch oporu wobec osmańskiej okupacji, a cechą charakterystyczną wilajetu Bośni była stała niesubordynacja wobec Turcji, której egzemplifikację stanowiło duże natężenie wystąpień różnej proweniencji przeciwko władzy padyszachów. Zdaniem Wacława Felczaka i Tadeusza Wasilewskiego, XIX wiek, który charakteryzował się reformami w państwie Osmanów, w Bośni i Hercegowinie, przebiegał pod znakiem buntów i represji przeciwko władzy ${ }^{48}$. $Z$ jednej strony ustanowiony porządek kontestowali muzułmańscy feudałowie, którzy byli przeciwnikami reform sułtana, walcząc o utrzymanie licznych przywilejów, z drugiej - protesty miały charakter społecznych wystąpień przeciwko nadużyciom władzy i dyskryminacji wynikającej z systemu feudalnego. Buntowała się zarówno ludność muzułmańska, jak też chrześcijańska, choć ta ostatnia początkowo na mniejszą skalę. Jak ocenił Milorad Ekmečić, u genezy większości wystąpień leżały nadmierne obciążenia ludności wiejskiej (która dominowała w Bośni i Hercegowinie ${ }^{49}$ ), przede wszystkim dziesięcina pobierana na rzecz spahijów, a następnie od 1858 r. - bezpośrednio do budżetu państwu, jak również konieczność oddawania feudałom jednej trzeciej dochodów ${ }^{50}$. Należy podkreślić, że muzułmańska szlachta do końca tureckiego panowania stanowiła zamkniętą kastę, która popierała system dyskryminacji ludności chrześcijańskiej, stanowiącej większość wśród chłopów świadczących

47 Dželal Ibraković stwierdził, że Bośnia i Hercegowina po podbiciu jej przez Osmanów zachowała swój szczególny status jako osobna jednostka administracyjna, kontynuując byt w sensie historycznym oraz kulturowym, D. Ibraković, Bosna, Islam - Bošnjaci (etnološko-povijesne skice), Fakultet političkih nauka, Sarajevo 2008, s. 113-114 et passim. Vide: H. Kamberović, Historiografija u Bosni i Hercegovini u službi politike, Srednja Europa, Zagreb 2012.

48 W. Felczak, T, Wasilewski, Historia Jugosławii...., s. 314.

49 Statystyki wskazywały, że nawet po trzydziestu latach od opuszczenia Bośni i Hercegowiny przez Turków przeszło 90\% mieszkańców prowincji stanowiła ludność wiejska, М. Екмечић, Историјски значај устанка у Босни и Хериеговини 1875-1878, [w:] М. Екмечић, Радови из историје Босне и Хериеговине XIX века, Београдски Издавачко Графички Завод, Београд, 1997, s. 206.

${ }^{50}$ M. Ekmečić wyróżnił dziewięć głównych podatków, którymi w XIX w. byli obciążeni chłopi, co zdaniem autora miało świadczyć o degeneracji systemu feudalnego w Bośni i Hercegowinie, Ibidem, s. 209, 210-212 et passim. 
powinności wynikające z sytemu feudalnego. W obliczu tych licznych sprzeczności nie dziwi fakt, że terytorium wilajetu stało się areną licznych wystąpień ludności. Pierwsze powstanie miało miejsce w 1603 r., a jego przywódcą był bośniacki namiestnik - Hasan Pasza Dželali. Do kolejnych zrywów ludności, w których dominowali muzułmanie, doszło w latach: 1636, 1650 i 1682. Podobne wystąpienia miały miejsce w Hercegowinie w latach: 1711, 1727, 1728, 1729, 1732. Sporadyczny udział w nich ludności chrześcijańskiej potwierdziły źródła osmańskie ${ }^{51}$. W latach 50. i 60. XVIII w. rozruchy przeciwko władzy zanotowano w Sarajewie, Livnie i Tuzli, gdzie na czele buntów często stawali miejscowi janczarzy, którzy starali się utrzymać swoje przywileje; ale liczne były również wystąpienia chłopów protestujących przeciwko podwyżkom podatków ${ }^{52}$. Przy czym trzeba podkreślić, że spiritus movens buntów feudałów była grupa najbardziej znaczących posiadaczy ziemskich, którzy zdobyli prawie nieograniczoną władzę w poszczególnych częściach sandżaków. Wyrazem ich buntu były liczne wystąpienia przeciwko władzy padyszachów (1747-1756, 1821, $1822,1826,1831)$. Za najbardziej istotne spośród nich należy uznać powstanie pod wodzą kapetana Huseina Gradaščevicia, znanego jako Zmaj od Bosne. W 1830 r. zbuntowani ajanowie sprzeciwiali się likwidacji korpusu janczarów, w którym służyli, ponadto zażądali autonomii dla Bośni, wraz z prawem wyboru własnego wezyra ${ }^{53}$. Mimo początkowych zwycięstw Gradaščevicia, jak również obietnic, iż zostanie wezyrem Bośni ${ }^{54}$, kolejne operacje wojsk tureckich doprowadziły do klęski dowodzonych przez niego oddziałów, zahamowania reform, wprowadzenia zcentralizowanej administracji i nałożenia stałych podatków ${ }^{55}$. Ruch pod przywództwem charyzmatycznego Huseina, podjęty w latach 1831-32, miał służyć wyłącznie interesom najbogatszych muzułmanów, chociaż paradoksalnie do powstania przyłączyli się również bośniaccy chrześcijanie, walczący w jednym szeregu z feudałami, którym płacili podatki. Wierzyli bowiem, iż wspólna walka przeciwko Turkom przyczyni się do ustanowienia autonomii Bośni i Hercegowiny. Zwycięstwo nad Osmanami miało także zapewnić zachowanie przywilejów elit miejskich, które w znaczący sposób były zaangażowane $\mathrm{w}$ te wystąpienia ${ }^{56}$.

${ }^{51}$ A. Giza, Bośnia i Hercegowina w dobie..., s.19 et passim; N. Malcolm, Bosnia ..., s. 86.

${ }^{52}$ M. Hadžijahić, Bune i ustanak u Bosni..., s. 99-116 et passim.

53 J. Skowronek, M. Tanty, T. Wasilewski, Historia Stowian Poludniowych..., s. 271.

${ }^{54}$ K. Kujawa, „Smok z Bośni” w tradycji bośniackich muzulmanów wczoraj i dziś, „Balcanica Posnaniensia. Acta et studia" 2010, nr XVII, s. 185.

55 Pamięć o Smoku z Bośni przetrwała stulecia, przeradzając się w kult tego bohatera, który stał się symbolem walki o niepodległy kraj. W czasie wojny domowej 1992-1995 w Tuzli wydawano radykalną muzułmańską gazetę, „Zmaj od Bosne”, w której nawoływano do utworzenia na terytorium Bośni i Hercegowiny państwa islamskiego. Po wojnie domowej Smok stał się elementem walki ideologicznej prowadzonej przez działaczy SDA z postkomunistami, K. Kujawa, „Smok z Bośni”...., s. 184-190 et passim. Vide: H. Kamberović, Husein-kapetan Gradaščević (1802-1834): Biografija uz dvjestu godišnjicu rođenja, BZK Preporod, Gradačac 2002; S. Šehić, Zmaj od Bosne: Husein - kapetan Gradaščević. Između legende i povijesti, Bosanska Riječ, Maribor 1994; M. Imamović, Historija Bošnjaka, BZK Preporod, Sarajevo 1997.

${ }^{56}$ Robert J. Donia, Sarajevo..., s. 52. 
Spacyfikowanie powstania Zmaja od Bosne nie zakończyło procesu narastania napięć społecznych i wystąpień ludności przeciwko władzy tureckiej. W 1833 r. sarajewscy muzułmanie odrzucili nakaz dotyczący reorganizacji armii osmańskiej, który przewidywał wprowadzenie nowych uniformów i noszenie fezu. W $1840 \mathrm{r}$. na czele buntowników stanął Ahmet Munib Glođo, jednak jego oddziały liczące 20000 żołnierzy zostały pobite przez siły lojalne sułtanowi ${ }^{57}$.

Ważnym wydarzeniem w dziejach prowincji stało się rozwiązanie korpusu janczarów oraz zamordowanie w 1836 r. tych spośród nich, którzy wystąpili przeciwko reformom armii, podjętym przez sułtana Mahmuda II ${ }^{58}$. Do 1837 r. zostały także zniesione kapetanije i kapetanowie, które, zdaniem Turków, były ogniskiem buntów przeciwko władzy centralnej. Jednak decyzje te, podobnie jak zlikwidowanie rady ajanów (notabli), reformy wojskowe oraz zniesienie pańszczyzny w $1848 \mathrm{r}$. - wywoływały następną falę niezadowolenia muzułmańskich feudałów. W tym samym mniej więcej doszło do kolejnych wystąpień, takich jak bunt chłopów bośniackich z 1834 r., na czele którego stanął pop Jovica Ilić5 ${ }^{59}$, a także protesty, które ogarnęły Hercegowinę w latach 1852-1855 oraz Bośnię (1857-1858) ${ }^{60}$. W zasadzie, jak podkreślili W. Felczak i T. Wasilewski, na terytorium paszałyków Bośni i Hercegowiny szczególnie dawał się we znaki permanentny kryzys władzy padyszachów i zmierzch ich imperium ${ }^{61}$.

Bunty i zamieszki zostały ugaszone w latach $1850-51$ przez poturczonego Chorwata Omera Paszę-Latasa, który złamał opór bośniackich feudałów i wprowadził reformy, służące umocnieniu władzy centralnej i kreowaniu nowego, wielokulturowego wizerunku Bośni i Hercegowiny ${ }^{62}$. Należy podkreślić, że Pasza Latas, co prawda, doprowadził do wykorzenienia najważniejszych przeciwników tanzimatu, lecz jednak zarządzana przez niego prowincja pozostawała jedną z nielicznych, w której zostały odroczone reformy wojskowe, zamiast nich utworzono jednostki ochotnicze, które jednak nie cieszyły się dobrą sławą, gdyż zarzucano im korupcję i nawiązanie do najgorszych tradycji przestarzałych, nieprofesjonalnych wojsk padyszachów ${ }^{63}$. Wraz z reformami Latasa, jak podkreślił prof. Henryk Batowski, zakończyła się epoka „złotej bośniackiej wolności”, przy czym wzniecane w tym okresie powstania miały już w pewnym sensie charakter narodowy i antyosmański ${ }^{64}$. W ich wyniku zislamizowani panowie bośniaccy utracili znaczącą pozycję polityczną i ekonomiczną na

${ }^{57}$ Ibidem, s. 53.

58 J. Reychman, Historia Turcji..., s. 209.

${ }^{59}$ W. Felczak, T. Wasilewski, Historia Jugostawii..., s. 313.

${ }^{60}$ A. Giza, Bośnia i Hercegowina w dobie..., s. 19.

${ }^{61}$ W. Felczak, T. Wasilewski, Historia Jugostawii..., s. 364.

${ }^{62}$ N. Makuljević, Tanzimat i vizuelno kreiranje javnog identiteta u Bosni i Hercegovini, [w:] Identitet Bosne i Hercegovine kroz historiju. Zbornik Radova, T. 2, Institut za Istoriju u Sarajevu, Sarajevo 2011, s. 214.

${ }^{63}$ Robert J. Donia, Sarajevo..., s. 58.

${ }^{64}$ H. Batowski, Państwa bałkańskie 1800 - 1923..., s. 68. 
rzecz feudałów tureckich (osmanlisów), natomiast ludność chrześcijańska zaczęła korzystać z prawa rozwoju szkolnictwa narodowego ${ }^{65}$.

W drugiej połowie XIX w. nadal nie ustawały niepokoje społeczne generowane przez ludność wiejską. Rozpoczęta w 1852 r. w Hercegowinie insurekcja chłopów prawosławnych trwała przez wiele lat, a na jej czele stał legendarny przywódca, Luka Vukalović, który współpracował z władzami czarnogórskimi, dążącymi do aneksji terytorium Hercegowiny ${ }^{66}$. W 1858 r. wybuchło krwawe powstanie chłopskie w Bośni, w którym wzięła udział ludność wyznania prawosławnego i katolickiego ${ }^{67}$. W $1859 \mathrm{r}$. został ogłoszony dekret, który sankcjonował samowolę feudałów, potwierdzając ich prawa do ziemi, a chłopów sprowadzając do pozycji niewolników.

Narastającej wraz z upływem czasu tendencji do coraz bardziej powszechnych buntów nie osłabiły reformy tanzimatu oraz wprowadzenie w 1856 r. reskryptu sułtańskiego, który teoretycznie zrównywał wobec prawa ludność chrześcijańską z muzułmańską. Prawo wolności wyznawanej religii, prawo nauczania, możliwość służby i kariery wojskowej w armii tureckiej - pozostawały tylko na papierze, nie dając faktycznych uprawnień niemuzułmanom, co sprzyjało niesubordynacji wobec władzy. Ponadto zasadą panowania Osmanów w Bośni i Hercegowinie stało się utrwalanie starego porządku feudalnego, czego przejawem był brak możliwości rozwoju chrześcijańskich instytucji społecznych, politycznych i kulturalnych ${ }^{68}$.

Warto także podkreślić, iż podejmowane były działania, które miały zmienić zacofane oblicze wilajetu. Reformy przeprowadzone przez Topala Šerifa Osmana Paszę, który zarządzał Bośnią w latach 1861-1869, doprowadziły do rozkwitu transportu, komunikacji oraz przemysłu ${ }^{69}$. Ustanowiono Radę Wilajetu, do której mogli wchodzić także chrześcijanie, chociaż faktycznie do końca panowania tureckiego w Bośni i Hercegowinie decydującą rolę odegrali w nim muzułmańscy feudałowie ${ }^{70}$. Mimo reformatorskiej działalności, Osman Pasza został dość szybko usunięty ze stanowiska, bowiem zaciążyły na nim zarzuty, iż sprzyjał ruchom autonomicznym, których celem było wywalczenie niezależności Bośni i Hercegowiny ${ }^{71}$.

Sprawą istotnej rangi i zarazem katalizatorem napięć społecznych była tzw. kwestia agrarna (agrarno pitanje). Mimo formalnego zniesienia pańszczyzny, w schyłkowej fazie panowania tureckiego, utrzymywał się stan wrzenia wśród ludności chłopskiej, bowiem elity muzułmańskie, bez względu na decyzje władzy centralnej,

\footnotetext{
65 J. Skowronek, M. Tanty, T. Wasilewski, Historia Stowian Południowych..., s. 271.

66 Efektem powstań w Hercegowinie, kontynuowanych w latach 1861-62, było uzyskanie czasowego zwolnienia z obciążeń feudalnych, w tym m. in. zwolnienie od dziesięciny, Ibidem, s. 356.

67 A. Giza, Bośnia i Hercegowina w dobie..., s. 24.

${ }^{68}$ W 1874 r. zniesiono, przyznaną chrześcijanom w 1856 r., autonomię oświatową i religijną, М. Екмечић, Историјски значај устанка..., s. 210-211.

69 W. Felczak, T. Wasilewski, Historia Jugosławii..., s. 343.

70 Robert J. Donia, Sarajevo..., s. 58.

71 M. Prelog, Povijest Bosne u doba osmanlijske vlade. I. Dio (1463-1739.), Izdavač Fortuna d. o.o., Sarajevo 1924 (reprint z 2009), s. 103.
} 
nakładały na chłopów coraz większe obciążenia podatkowe ${ }^{72}$. Brak gwarancji zachowania równych praw ludności muzułmańskiej i chrześcijańskiej, mimo prób wprowadzania reform przez władzę centralną, stworzył kolejne zarzewie niegasnących konfliktów, które na trwale wpisały się w historię Bośni i Hercegowiny.

W ten sposób w XIX w. ukształtował się paradygmat bośniackiej niestabilności, który wpisuje się w szerszy kontekst paradygmatu bałkańskiej niestabilności. Zgodnie z nim Półwysep Bałkański można scharakteryzować jako region pełen napięć, gdzie w perspektywie historycznej występowały liczne podboje i wynikające z nich kontrowersje, co do ustalenia granic państwowych, jak też nierozwiązane konflikty narodowościowe i etniczne. Zdaniem serbskiego naukowca, Ljubišy R. Mitrovicia, terytorium Bałkanów, jako skrzyżowanie cywilizacji, dotknięte jest syndromem „szoku przeszłości”, który sprawia, iż z powodu uwarunkowań historycznych i geopolitycznych stale występuje w tym regionie niebezpieczeństwo napięć, konfliktów, starć militarnych i wojen ${ }^{73}$.

\section{OD REWOLUCJI SPOŁECZNEJ DO POWSTANIA NARODOWEGO. ZNACZNIE INSUREKCJI W BOŚNI I HERCEGOWINIE W LATACH 1875-1878}

W drugiej połowie XIX w. w wielu prowincjach Imperium Otomańskiego narastało niezadowolenie spowodowane niewydolnością reform podjętych $\mathrm{w}$ ramach tanzimatu, które nie przynosiły korzyści poddanym w odległych prowincjach państwa padyszacha, gdzie gra pozorów ze strony lokalnej administracji zastępowała oczekiwaną od dawna przez poddanych sanację państwa ${ }^{74}$. Szczególnego znaczenia nabrały protesty w Bośni i Hercegowinie, gdzie krytykowano rosnące z każdym rokiem obciążenia fiskalne, a przede wszystkim samowolę urzędników, którzy wielokrotnie w ciągu roku w sposób dowolny zwiększali wysokość podatku. Chrześcijanie skarżyli się nie tylko na wyzysk ekonomiczny, lecz także na dyskryminację społeczną i kulturową, sprawiającą, iż byli postrzegani przez osmanlisów jako obywatele gorszej kategorii. Wiele żądań, dotyczących zrównania praw chrześcijan z prawami muzułmanów, zapewnienie faktycznej wolności wyznania,

\footnotetext{
72 Faktycznie pańszczyzna została zlikwidowana dopiero na mocy reformy rolnej w Królestwie SHS (następnie Królestwie Jugosławii) przeprowadzonej w latach 1919-1931. Chociaż nadal agrarno pitanje pozostawało kwestią sporną, bowiem podjęte reformy nie rozwiązały wszystkich problemów obszarów wiejskich Bośni i Hercegowiny, doprowadzając m.in. do rozdrobnienia gospodarstw rolnych i dalszej pauperyzacji mieszkańców wsi, jak też konieczności migracji ludności wiejskiej do miast, Iván T. Berend i György Ránki, Economic development in East-Central Europe in the nineteenth and twentieth centuries, „Acta Historica Academiae Scientiarum Hungaricae”, No. 3/4, s. 318-320.

73 L. R. Mitrović, Balkan. Granica i most među narodima. (Ogledi iz sociologije regionalnog razvoja), Zavod za udžbenike i nastavna sredstva, Beograd 2000, s. 9-14.

74 Erik J. Zürcher, Turcja. Od sułtanatu do wspótczesności, Wyd. Uniwersytetu Jagiellońskiego, Kraków 2013, s. 54-55.
} 
zlikwidowania nadużyć w systemie pobierania podatków, zaprzestania prześladowań kobiet chrześcijańskich oraz niszczenia kościołów - kierowano bezpośrednio do Stambułu ${ }^{75}$. Jednak brak zdecydowanego odzewu władzy centralnej przygotował warunki do wybuchu insurekcji - tym razem na znacznie szerszą skalę. Poprzedziło ją wiele mniej znaczących, spontanicznych buntów, które nie posiadały określonego charakteru politycznego, ani przywódcy, zaś ich celem była głównie chęć zrzucenia ciężarów feudalnego nakładanych przez muzułmańskich posiadaczy. W zasadzie od 1871 r. notowano liczne wystąpienia chłopów prawosławnych, które miały miejsce zarówno w Bośni, jak i Hercegowinie, do których przyłączyli się także muzułmanie i katolicy ${ }^{76}$. Insurekcja roku 1875 w Hercegowinie niewątpliwie stanowiła na początku bunt typowo chłopski, który bardzo szybko rozprzestrzenił się na terytorium Bułgarii, Serbii i Czarnogóry, przybierając charakter ogólnobałkańskiego powstania przeciwko panowaniu tureckiemu na Bałkanach. Najpierw ognisko rewolty rozpaliło się w okolicach Nevesinje, gdzie hajducy w lipcu 1875 r. zaatakowali tureckich kupców. Następnie w ciągu miesiąca wystąpienia ogarnęły prawie całą Hercegowinę, a w sierpniu walki rozpoczęły się także w Bośni, gdzie uderzono na główne miasta prowincji. Bardzo szybko ruch, zyskujący poparcie wielu ochotników z Europy Wschodniej i Południowej, zaczął odnosić liczne sukcesy; powstańcy m. in. zdobyli wiele umocnień i garnizonów, w których zlikwidowano władzę Osmanów. Niemniej jednak jego głównym mankamentem był brak jednolitego ośrodka kierowania i dowodzenia. Działania prowadzone były bowiem przez niezależne grupy powstańcze (czety), pod dowództwem wojewodów (m. in. Mico Ljubibratić, Lazar Sočić, Petar Petrović - Pecija oraz inni), których lokalne zwycięstwa nad oddziałami tureckimi nie mogły zapewnić powodzenia całemu powstaniu ${ }^{77}$. W trakcie insurekcji istotne znaczenie miało szerokie oddziaływanie idei: jugoslawizmu, panslawizmu oraz socjalizmu, których reprezentanci zmagali się o rząd dusz Słowian walczących z upadających państwem padyszachów. Za szczególnie niebezpieczne zarówno dla Turcji, jak i mocarstw zachodnich, należy uznać idee jugoslawizmu, wysuwające hasła zjednoczenia Bośni i Hercegowiny z Serbią i Czarnogórą ${ }^{78}$. Dla dyplomatów z Belgradu w ramach programu Načertanije prowincja ta stanowiła terytorium, które miało zostać włączone do Serbii, co postulowano jeszcze w czasie pierwszego serbskiego powstania $^{79}$. Dlatego też zabiegi Belgradu od lat 60 . XIX w. koncentrowały się wokół

75 A. Giza, Bośnia i Hercegowina w dobie..., s. 65.

76 Początkowo katolicy i muzułmanie pisali skargi do sułtana, a gdy nie zyskali odpowiedzi, zaprzestali płacenia podatków, co zubożyło wyczerpane wojnami i klęskami suszy państwo padyszachów, M. Glenny, The Balkans 1804-1999..., s. 101.

77 J. Skowronek, M. Tanty, T. Wasilewski, Historia Stowian Poludniowych..., s. 398.

78 Robert J. Donia, John V. A. Fine, Jr., Bosna i Hercegovina ..., s. 84.

${ }^{79}$ S. Oljunin, Sociokulturnyj oblik Bosni v epohu preobrazovanij, „Slavia Meridionalis. Studia Linguistica Slavica et Balcanica", nr 8, 2008, s. 176. Powstanie pod wodzą Jerzego Czarnego Karadjordje (pierwsze powstanie serbskie), do którego doszło w latach 1804-1813, nie mogło objąć Bośni i Hercegowiny, gdyż nie było przywódców gotowych porwać ludność do walki. Jednocześnie wysiłki chrześcijańskich mieszkańców były pacyfikowane przez wierną kapetanom ludność muzułmańską, W. Felczak, T. Wasilewski, Historia Jugostawii..., s. 266. 
przygotowania do insurekcji w Bośni i Hercegowinie. W tym celu specjalny komitet z siedzibą w Belgradzie zorganizował sieć tajnych agend w Sarajewie, Banja Luce, Mostarze, Dubrowniku, Kotorze i Nowym Sadzie. Przygotowywały one Serbów bośniackich do powstania przeciwko Turcji i jednocześnie zabiegały o pomoc serbskich oficerów z Pogranicza Wojskowego. Po zawarciu porozumienia z Chorwatami, Serbia planowała zajęcie Bośni i oraz powołanie do życia państwa jugosłowiańskiego ${ }^{80}$.

Poparcia powstańcom udzielili także rosyjscy panslawiści, których liderem był Iwan Aksakow. Mieli oni nadzieję na zjednoczenie Słowian pod berłem cara, aby W ten sposób umocnić pozycję Rosji na Bałkanach ${ }^{81}$. W wystąpieniach znalazły odzwierciedlenie również nurty socjalistyczne. Za najbardziej radykalny należy uznać program wysunięty przez socjalistę, Vasę Pelagicia, który uzyskał znaczące wpływy w bośniackiej Krainie. Jego zwolennicy postulowali zjednoczenie Bośni z Serbią, a następnie zbudowanie państwa demokratycznego, w ramach którego doszłoby do całkowitego uwłaszczenia chłopów ${ }^{82}$.

Warto podkreślić, iż we wszystkich tych programach uwzględniano scenariusze, zgodnie z którymi na gruzach Imperium Otomańskiego powstać miały niezależne państwa słowiańskie, co nie zawsze było adekwatne do oczekiwań wielkich mocarstw, które chciały mieć decydujący wpływ na wydarzenia zachodzące na Bałkanach.

Insurekcja bośniacka pod względem rozmachu przerosła wszystkie dotychczasowe powstania antytureckie, stając się inspiracją dla pozostałych Słowian bałkańskich do zrzucenia tureckiego jarzma. 2 maja 1876 r. walkę z Turkami rozpoczęli Bułgarzy. Kiedy jednak ich wystąpienia zostały krwawo stłumione, głównie przez nieregularne oddziały baszybuzków, które popełniły wiele okrucieństw, mordując ludność cywilną, a także pustosząc wioski i miasta, za broń chwycili Serbowie i Czarnogórcy, którzy wypowiedzieli wojnę Turcji ${ }^{83}$. Książę czarnogórski, Mikołaj i książę serbski, Milan, związali się dwustronnym sojuszem, który zawierał klauzulę o przejęciu przez Serbię - Bośni, a przez Czarnogórę - Hercegowiny. W efekcie tych ustaleń powstańcy bośniaccy pod wodzą Goluba Babicia 2 lipca 1876 r. ogłosili zjednoczenie Bośni z Serbią, natomiast powstańcy w Hercegowinie uznali zwierzchność księcia Mikołaja ${ }^{84}$.

Wielkie mocarstwa, które rozpoczęły już między sobą rozgrywkę o schedę po upadającym państwie sułtanów, nie były zainteresowane ruchami rewolucyjnymi na Bałkanach, dopóki nie zagrażały one ich interesom ${ }^{85}$. Zaniepokojenie wywołało dopiero ogłoszenie przez Bośniaków zjednoczenia z Serbią. Rosja, która mianowała się

\footnotetext{
${ }^{80}$ A. Giza, Idea jugoslawizmu..., s. 145.

81 M. Tanty, Konflikty bałkańskie..., s. 20.

${ }^{82}$ W koncepcjach przedstawionych przez Vasę Pelagicia, Bośnia i Hercegowina miała stanowić monarchię konstytucyjną, co prawdą połączoną osobą władcy z Serbią, ale posiadającą odrębny parlament oraz rząd, V. Pelagić, Istorija bosansko-hercegovačke bune, Svjetlost, Sarajevo 1953, s. 130-131.

${ }^{83}$ M. Tanty, Bałkany w XX wieku..., s. 16.

${ }^{84}$ A. Giza, Bośnia i Hercegowina $w$ dobie..., s. 74.

85 M. Glenny, The Balkans 1804-1999..., s. 128.
} 
protektorką Słowian, poszukiwała na drodze dyplomatycznej korzystnych dla narodów bałkańskich rozwiązań. Jesienią 1876 r., kiedy Serbia odnosiła dotkliwe porażki z wojnie z Portą, Rosja starała się uzyskać poparcie mocarstw dla zawarcia rozejmu z Turcją. Po osiągnięciu tego celu, dzięki zabiegom dyplomacji brytyjskiej, 23 grudnia 1876 r. doszło do zwołania konferencji w Stambule z udziałem przedstawicieli Wielkiej Brytanii, Rosji, Austro-Węgier, Niemiec, Włoch i Turcji. W tym samym dniu sułtan Abdülhamid II ogłosił nadanie państwu nowej konstytucji. Aby spacyfikować obrady, Turcy oświadczyli, iż nowy akt prawny przewidywał przeprowadzenie reform na Bałkanach, które miały zrealizować postulaty mieszkańców Bośni i Hercegowiny, a także Bułgarii. W obliczu tych oświadczeń - 28 lutego 1877 r. pokój z Turcją podpisała Serbia, lecz Czarnogóra kontynuowała walkę z państwem padyszachów ${ }^{86}$. W ten sposób konflikt został odroczony, lecz wobec braku chęci Turcji do zrealizowania ustaleń stambulskich, wkrótce walki rozgorzały na nowo, doprowadzając do aktywnego zaangażowania się mocarstw: Wielkiej Brytanii, Austro-Węgier i Rosji.

W kwietniu 1877 r. Rosja przystąpiła do wojny przeciwko Turcji pod hasłem wyzwolenia narodów bałkańskich spod panowania Osmanów ${ }^{87}$. Działania wojenne były prowadzone na dwóch frontach: bałkańskim i kaukaskim. Po wielu sukcesach rosyjskich, które zbliżyły armię wielkiego księcia Mikołaja Mikołajewicza do Adrianopola, nastąpiło załamanie się wojsk osmańskich oraz rozpoczęcie negocjacji rozejmowych, w wyniku których 3 marca 1878 r. został podpisany traktat pokojowy w San Stefano. $\mathrm{Na}$ mocy jego postanowień Serbia, Czarnogóra oraz Rumunia uzyskiwały niepodległość oraz nabytki terytorialne, natomiast Bośnia i Hercegowina miała pozostać w składzie państwa padyszachów. Zamierzano także powołać do życia wasalne wobec Turcji wielkie państwo bułgarskie (z Tracją i Macedonią), ale w istocie o dużym stopniu niezależności, bowiem wojska tureckie miały opuścić jego terytorium, natomiast Rosji zagwarantowano utrzymywanie tam przez dwa lata sił zbrojnych. Tak stworzona Wielka Bułgaria gwarantowałaby Moskwie kontrolowanie cieśnin Bosfor i Dardanele, bowiem granica Bułgarii miała przebiegać blisko Stambułu ${ }^{88}$.

Postanowienia traktatu, uznanego za początek rozbioru Turcji ${ }^{89}$, zaniepokoiły Austro-Węgry i Wielką Brytanię, które obawiając się wzrostu znaczenia Rosji i bałkańskich państw słowiańskich, dążyły do jego rewizji. Roszczenia monarchii habsburskiej polegały na tym, iż nie otrzymała ona wcześniej obiecanych nabytków terytorialnych w Bośni i Hercegowinie. Wiedeń obawiał się ponadto, iż wyznawcy jugoslawizmu mogą zatriumfować, widzieli oni bowiem w wojnie rosyjsko-tureckiej 1877-1878 wielką szansę wyzwolenia Bośni i Hercegowiny oraz Sandżaku Nowopazarskiego spod panowania tureckiego. Wielka Brytania i Francja, obawia-

86 M. Tanty, Bałkany w XX wieku..., s. 18.

${ }^{87}$ Rosję wsparła Czarnogóra oraz Rumunia, która 21 maja 1877 r. proklamowała niepodległość. 2 lutego 1878 r. przeciwko Turcji wystąpiła także Grecja, Ibidem, s. 19 - 20.

88 Rosji została przyznana wysoka kontrybucja oraz kilka twierdz na Kaukazie. Serbia i Czarnogóra otrzymały znaczne nabytki terytorialne, natomiast Rumunia zyskała północną Dobrudżę, ale musiała zrzec się na rzecz Rosji - Besarabii, Ibidem, s. 20.

89 J. Reychman, Historia Turcji..., s. 247. 
jąc się wzmocnienia Rosji kosztem Turcji, doprowadziły do zwołania kongresu berlińskiego, który miał osłabić państwa słowiańskie i umocnić pozycję Wiednia na Bałkanach $^{90}$.

\section{W LABIRYNCIE „WIELKIEGO KRYZYSU WSCHODNIEGO”. OKUPACJA BOŚNI I HERCEGOWINY}

Podczas kongresu berlińskiego (13 czerwca - 13 lipca 1878 r.) Austro-Węgry forsowały okupację Bośni i Hercegowiny, aby prowincja nie dostała się pod panowanie Serbii i Czarnogóry. Jak podkreślił Milorad Ekmečić, pojawiły się wówczas szanse dla realizacji planu jugosłowiańskiego dla tej prowincji, ale nie zostały one zrealizowane, doprowadzając do zaprzepaszczenia wysiłków uczestników ogólnobałkańskiego powstania ${ }^{91}$. Rzeczywiście, ustalenia kongresu stanowiły klęskę dla zwolenników jugoslawizmu, gdyż wielkie mocarstwa za wszelką cenę starały się nie dopuścić do utworzenia państwa Słowian Południowych, które mogłyby zagrażać ich wpływom w tej części Starego Kontynentu. Ład zaproponowany na kongresie berlińskim miał służyć przede wszystkim ugruntowaniu pozycji najsilniejszych graczy, ze szkodą dla Słowian, których polityczne ambicje kolidowały z interesami mocarstw zachodnich. Szczególnie zaciekłym wrogiem Słowian okazała się dyplomacja angielska, która broniła resztek świetności Imperium Otomańskiego, uznając, że zjednoczone państwo słowiańskie stanowiłoby zagrożenie dla Turcji. Odrzucono także ideę bośniackiej autonomii, stwierdzając, iż mogłaby wywołać niezadowolenie ludności chrześcijańskiej i spowodować wybuch nowych zamieszek, na osi konfliktu z muzułmańskimi feudałami. Wiedeń za jedyne możliwe wyjście z „labiryntu kryzysu wschodniego” uważał okupację Bośni i Hercegowiny ${ }^{92}$. Kongres berliński uregulował tzw. kwestię wschodnią w ten sposób, że wzmocniona została pozycja Austro-Węgier, które zresztą nie brały udziału w wojnie 1877-1878 z Portą, zyskały jednak władzę cywilną oraz wojskową nad Bośnią i Hercegowiną na okres 30 lat ${ }^{93}$. Pozostałe ustalenia również były niekorzystne dla młodych państw bałkańskich: co prawda została potwierdzona niepodległość Rumunii, tak samo jak i Serbii oraz Czarnogóry, ale terytoria dwóch państw słowiańskich zostały okrojone o nabytki uzyskane w San Stefano. Także Bułgarzy nie byli zadowoleni z podjętych decyzji, gdyż zniweczony został ich sen o Wielkiej Bułgarii poprzez ustanowienie wasalnego Księstwa Bułgarskiego oraz autonomicznej Rumelii Wschodniej. Tureckie panowanie zostało natomiast zachowane w Macedonii i Tracji ${ }^{94}$.

\footnotetext{
${ }^{90}$ Robert J. Donia, John V. A. Fine, Jr., Bosna i Hercegovina ..., s. 84.

91 М. Екмечић, Историјски значај устанка..., s. 251.

92 Idem, Ustanak u Bosni 1875-1878, Veselin Masleša, Sarajevo 1960, s. 352.

93 V. Dedijer, Sarajevo 1914, T. I, Wyd. Łódzkie, Łódź 1984, s. 80-84.

94 M. Tanty, Batkany w XX wieku..., s. 21.
} 
Społeczeństwo Bośni i Hercegowiny niejednoznacznie oceniło fakt wkroczenia wojsk austriackich. Jedynie ludność chorwacka, wyznania katolickiego, witała oddziały austriackie jako wybawicieli. Perspektywa dostania się pod panowanie Wiednia podzieliła bośniackich muzułmanów: bogaci i wpływowi, związani z władzami upadającego imperium padyszachów, poparli ustalenia kongresu, sądząc, iż nowi zarządcy pozwolą im zachować dotychczasowe przywileje ${ }^{95}$. Z kolei muzułmanie z klas niższych, szczególnie mieszkańcy miast, głośno sprzeciwiali się tym decyzjom, obawiając się, że Austriacy będą przychylniej traktować chrześcijan oraz nie zapewnią wyznawcom islamu autonomii. W miejscowości Maglaj, liderzy muzułmańscy ogłosili kapitulację, ale część mieszkańców zatarasowała ulice, walcząc z wkraczającymi oddziałami austriackimi. Sarajewo zostało zajęte po ciężkich walkach 18 sierpnia 1878 r. ${ }^{96}$. W bitwie o Ključ 4 i 5 września 1878 r. oddziały okupacyjne straciły ponad 300 żołnierzy, ale powstańcy musieli się wycofać. Starcia zbrojne miały miejsce także w Krajinie bośniackiej, gdzie operację zakończono 9 września 1878 r. Oszacowano, iż w walkach w Bośni i Hercegowinie od początku powstania antytureckiego do momentu zakończenia wystąpień przeciwko wojskom monarchii habsburskiej zginęło prawie 150000 osób $^{97}$.

Austriackie rządy nie zlikwidowały wadliwego systemu społeczno-ekonomicznego, chłopi byli więc wciąż poddani obciążeniom feudalnym, tak jak w czasach panowania tureckiego. Mogli, co prawda, wykupić się od ucisku pańszczyźnianego, ale zazwyczaj nie posiadali odpowiednich funduszy. Nadal zmuszeni byli do oddawania trzeciej części zbiorów agom i bejom, co stało się ogniskiem kolejnych buntów w Stolacu, Livnie, Zvorniku i innych miejscowościach ${ }^{98}$. Bośnia i Hercegowina w oczach Wiednia nie cieszyła się dobrą sławą, uznawano ją za region trudny i niebezpieczny. Warto zauważyć, że stan permanentnej niestabilności nie został złagodzony wraz z ustanowieniem nowego porządku na Bałkanach ${ }^{99}$. Na przestrzeni wieków prowincja stanowiła kwintesencję problematyki bałkańskiej, a jej cechą dystynktywną stało się społeczeństwo, które można scharakteryzować jako heterogeniczne, rozbite, pozbawione wewnętrznych więzi, nie posiadające politycznych i kulturowych liderów, którzy mogliby sprzyjać ideom unifikacyjnym ${ }^{100}$. Niewątpliwie mocarstwa zachodnie doceniały jej znaczenie w kategoriach geopolitycznych, czego egzemplifikacją stały się słowa, które po kongresie berlińskim, wypowiedział Gyula Andrássy, minister spraw zagranicznych Austro-Węgier. Polityk stwierdził, że wręcza cesarzo-

95 Robert J. Donia, Sarajevo..., s. 63.

${ }^{96}$ A. Giza, Bośnia i Hercegowina w dobie..., s. 87.

97 Ibidem, s. 89.

${ }^{98}$ Ibidem, s. 93.

99 Vide: T. Kraljačić, Kalajev režim u Bosni i Hercegovini 1882-1903, Veselin Masleša, Sarajevo 1987.

${ }^{100}$ My już jesteśmy zjedzeni... Rola i znaczenie prawosławia w konflikcie etnicznym w Dolinie Preszewa, praca zbiorowa pod red. R. Zenderowskiego, Wyd. Instytut Politologii Uniwersytetu Kardynała Stefana Wyszyńskiego w Warszawie, Warszawa 2012, s. 17 et passim. 
wi Franciszkowi Józefowi I „klucz” do Bałkanów ${ }^{101}$. Interpretacja wydarzeń zachodzących na tym terytorium miała i ma więc istotne znaczenie dla oceny sytuacji politycznej sensu largo na Półwyspie Bałkańskim.

\section{WNIOSKI I REKOMENDACJE}

Regionalna historiografia państw narodowych na Półwyspie Bałkańskim oceniła, że okres panowania tureckiego w tej części Europy stanowił „niewolę babilońską”, naznaczoną okrucieństwem barbarzyńską inwazję, pełną przemocy i zniewolenia narodów bałkańskich, które musiały walczyć z okupantem. Z kolei historycy tureccy poszukiwali dla państwa padyszachów usprawiedliwienia, stwierdzając, iż porządek osmański umożliwiał wszechstronny rozwój podbitych narodów, zachowując ich porządek socjalny, język, religię i kulturę ${ }^{102}$. Nie zwrócono jednak uwagi na to, że rządy osmańskie na Bałkanach zaburzyły harmonijny rozwój tego regionu, wpędzając go w zapaść cywilizacyjną, i zarazem stwarzając podłoże do rozwoju następnych wojen i konfliktów.

Należy podkreślić, że w uwarunkowaniach społecznych, politycznych i militarnych Bośni i Hercegowiny w XIX w. odzwierciedlone zostały wszystkie mankamenty odchodzącego w cień historii Imperium Osmanów. Bezsprzecznie w końcowej fazie istnienia państwa sułtanów bunty i powstania wstrząsały całym jego terytorium, lecz wilajet Bośni stanowi swoiste lustro, w którym najpełniej uwydatniły się problemy „chorego człowieka Europy”. W tej prowincji, gdzie w wyniku panowania tureckiego ukształtowało się podzielone religijnie i kulturowo społeczeństwo, bez określonej tożsamości narodowej, powstały specyficzne warunki do wzniecenia buntów, które w znaczny sposób odebrały Osmanom nadzieje na renesans ich imperium. Niestabilna sytuacja, jaka miała miejsce prawie przez cały okres panowania osmańskiego, sprzeczności wynikające z przestarzałego systemu feudalnego, fiasko reform tanzimatu, wreszcie chłopska insurekcja, która przekształciła się w ogólnobałkańskie powstanie - implikowały ukształtowanie się paradygmatu bośniackiej niestabilności, w znaczny sposób burząc marzenia Turków o dawnej świetności.

Dziedzictwo osmańskie zdeterminowało także dzieje współczesnej Bośni i Hercegowiny, na której terytorium znajdują odbicie wszystkie konflikty oraz napięcia, narastające w ciągu wieków. Do dzisiaj wpływają one na losy tego kraju, który jest charakteryzowany jako państwo niestabilne, upadające, a budowa jednolitego narodu w podzielonym społeczeństwie staje się prawie niemożliwa. Odżywające w XXI w. idee neoosmańskie, które nawiązują do tureckiego panowania na Bałkanach, stanowią kolejny dowód na ścisły związek tego obszaru z dziedzictwem tureckim, a eks-

${ }^{101}$ Le régime politique d'Autrichee-Hongrie en Bosnie-Herzégovine et les procès de haute trahison, Imprimerie Nouvelle, Annemasse 1916, s. 24.

102 E. Boyar, Ottomans, Turks and the Balkans. Empire lost, relations altered, Tauris Academic Studies, London-New York 2007, s. 141-146. 
pansja gospodarcza oraz niezwykle dynamiczne (by nie powiedzieć agresywne) tworzenie centrów kultury islamskiej w Bośni i Hercegowinie, Albanii, Kosowie - mogą sprawiać wrażenie, że powrót Turcji na Bałkany niekoniecznie musi mieć wyłącznie charakter stabilizatora sytuacji, równie dobrze może stanowić dowód na ekspansywny charakter polityki mocarstwowej Ankary i chęć renesansu dawnej strefy wpływów ${ }^{103}$.

\section{BIBLIOGRAFIA}

Aronson Theo, Zwaśnieni monarchowie. Europejskie trony w przeddzień katastrofy 1914 roku, Wyd. Literackie, Kraków 2014.

Batowski Henryk, Państwa bałkańskie 1800 - 1923. Zarys historii dyplomatycznej i rozwoju terytorialnego, Skł. gł.: Kasa im. Mianowskiego w Warszawie, Kraków 1938.

Batowski Henryk, Podstawy sojuszu batkańskiego 1912. Studia z historii dyplomatycznej 1806-1912, Polskie Towarzystwo dla Badań Europy Wschodniej i Bliskiego Wschodu, Kraków 1939.

Bazin Marcel, Tapia de Stéphane, Turcja geografia wschodzacej potęgi, Dialog, Warszawa 2014.

Donia Robert J., Sarajevo: biografija grada, Institut za Istoriju u Sarajevu, Sarajevo 2006.

Donia Robert J., Fine, Jr., John V. A., Bosna i Hercegovina: iznevjerena tradicija, Institut za Istoriju u Sarajevu, Sarajevo 2011.

Džaja M., Srećko, Konfesionalnost i nacionalnost Bosne i Hercegovine. Predemancipacijsko razdoblje 1463.-1804., ZIRAL, Mostar 1999.

Dzieje gospodarcze i społeczne imperium osmańskiego 1300-1914, red. Halil Inalcik, Donald Quataert, Wyd. Uniwersytetu Jagiellońskiego, Kraków 2008.

Ekmečić Milorad, Ustanak u Bosni, Veselin Masleša, Sarajevo 1960.

Екмечић Милорд, Радови из историје Босне и Херцеговине XIX века, БИГЗ, Београд, 1997.

Felczak Wacław, Wasilewski Tadeusz, Historia Jugosławii, Zakład Narodowy im. Ossolińskich, Wrocław 1985.

Filipović Muhamed, Bosna i Hercegovina, najvažnije geografske, demografske, historijske, kulturne i političke činjenice, Compact-E, Sarajevo 1997.

Giza Antoni, Idea jugoslawizmu w latach 1800-1918, Wyd. Naukowe US, Szczecin 1992.

Glenny Misha, The Balkans 1804-1999. Nationalism, War and the Great Power, Viking, London 2000.

Hadžijahić Muhamed, Neki rezultati ispitivanja etničkih kretanja u Bosni u XVIII i prvoj polovici XIX stoljeća, „Prilozi Instituta za istoriju”, br. 11/12, 1976.

Identitet Bosne i Hercegovine kroz historiju. Zbornik Radova, T. 2, Institut za Istoriju u Sarajevu, Sarajevo 2011.

Imamović Mustafa, Historija države i prava, Magistrat Sarajevo, Sarajevo 2003.

Jelavich Barbara, Historia Batkanów. Wiek XVIII i XIX, T. I., Wyd. Uniwersytetu Jagiellońskiego, Kraków 2005.

Kamberović Husnija, Husein-kapetan Gradaščević (1802-1834): Biografija uz dvjestu godišnjicu rođen$j a$, BZK Preporod, Gradačac 2002.

Konflikty militarne i niemilitarne na Bałkanach $w$ XX $i$ XXI wieku w perspektywie polemologicznej, pod red. Danuty Gibas-Krzak i Andrzeja Krzaka, Wyd. Zapol, Szczecin-Warszawa 2013.

Koseski Adam, Albania. Krótki zarys dziejów, Książka i Wiedza, Warszawa 1988.

Kraljačić Tomislav, Kalajev režim u Bosni i Hercegovini 1882-1903, Veselin Masleša, Sarajevo 1987.

103 Vide: D. Танасковић, Неоосманизам - повратак Турске на Балкан: доктрина и спољнополитичка пракса, Службени гласник, Београд 2010. 
Le régime politique d'Autrichee-Hongrie en Bosnie-Herzégovine et les procès de haute trahison, Imprimerie Nouvelle, Annemasse 1916.

Lewis Bernard, Narodziny nowoczesnej Turcji, PWN, Warszawa 1972.

Malcolm Noel, Bosnia. A short history, Pan Books, London 2002.

Mitrović R. Ljubiša, Balkan. Granica i most među narodima. (Ogledi iz sociologije regionalnog razvoja), Zavod za udžbenike i nastavna sredstva, Beograd 2000.

Morawski Wojciech, Szawłowska Sylwia, Wojny rosyjsko-tureckie od XVII do XX wieku, Wyd. Trio, Warszawa 2006.

Пејановић Ђорђе, Становништво Босне и Херцеговине, Српска Академија Наука, Београд 1955.

Prelog Milan, Povijest Bosne u doba osmanlijske vlade. I. Dio (1463-1739.), Izdavač Fortuna d. o.o., Sarajevo 1924 (reprint z 2009).

Skowronek Jerzy, Tanty Mieczysław, Wasilewski Tadeusz, Historia Stowian Poludniowych i Zachodnich, PWN, Warszawa 1988.

Танасковић Dарко, Неоосманизам - повратак Турске на Балкан: доктрина и спољнополитичка пракса, Службени гласник, Београд 2010.

Tanty Mieczysław, Konflikty bałkańskie w latach 1878-1918, Państwowe Zakłady Wydawnictw Szkolnych, Warszawa 1968.

Tanty Mieczysław, Bosfor i Dardanele w polityce mocarstw, PWN, Warszawa 1982.

Tanty Mieczysław, Bałkany w XX wieku. Dzieje polityczne, Książka i Wiedza, Warszawa 2003.

Weibel Ernest, Histoire et géopolitique des Balkans de 1800 à nos jours, Ellipses, Paris 2002.

Wituch Tomasz, Tureckie przemiany. Dzieje Turcji 1878-1923, PWN, Warszawa 1980.

Wróbel Piotr, Krzyż i Półksiężyc. Zachodnie Bałkany wobec Turcji w latach 1444-1463, Wyd. Historia Iagellonica, Kraków 2000.

Wróbel Piotr, Oblicza islamizacji na terenach Bośni w XV i połowie XVI wieku, „Balcanica Posnaniensia. Acta et studia" nr XVIII, 2001.

Zürcher J. Erik, Turcja. Od sultanatu do wspótczesności, Wyd. Uniwersytetu Jagiellońskiego, Kraków 2013. 